\title{
Two new species of the catfish genus Trichomycterus (Siluriformes: Trichomycteridae) from the rio Ribeira de Iguape Basin, Southeastern Brazil
}

\author{
Wolmar Benjamin Wosiacki* and Osvaldo Takeshi Oyakawa**
}

Two new species of the trichomycterid catfish genus Trichomycterus from the rio Ribeira de Iguape basin, southeastern Brazil, are described. Trichomycterus tupinamba differs from the other species of the Trichomycterinae in having the first pectoral-fin ray not prolonged as a filament, the caudal fin is truncate with attenuated edges, two paired supraorbital pores s6, eye oriented dorsally, a subterminal mouth, anal and urogenital openings mid-way between the pelvic-fin margin and anal-fin origin, a dark spot at the base of the nasal barbel, a longitudinal row of dark spots along the midline of the flank from the opercle to the caudal-fin base, a pectoral-girdle width of 13.1-17.7\% of standard length, and a caudal-peduncle depth of 8.7-10.3 \% of standard length. Trichomycterus jacupiranga differs from all other species of the Trichomycterinae in having the first pectoralfin ray prolonged as a short filament, one fused supraorbital pore s6, a pelvic fin that covers the anal and urogenital openings, anal and urogenital openings that are closer to the anal-fin origin than to the pelvic-fin base, a truncated caudal fin with attenuated edges, and the following morphometric characteristics: head length 20.7-22.4 \% standard length, preanal length 57.1-70.9 \% standard length, pectoral girdle width 17.4-20.6 \% standard length, trunk length 33.6-37.5\% standard length, pectoral-fin length 16.8-22.7\% standard length, dorsal-fin base length 12.8-14.1\% standard length, anal-fin base length 8.4$10.8 \%$ standard length, head width 90.6-104.6\% head length, snout length 40.0-46.9 \% head length, mouth width $27.0-37.3 \%$ head length, and eye diameter 10.4-16.5\% head length. Distribution, ecological data and diagnostic features are presented for both new species.

Duas espécies novas de Trichomycterus da bacia do rio Ribeira de Iguape são descritas. Trichomycterus tupinamba difere das demais espécies de Trichomycterinae por apresentar o primeiro raio da nadadeira peitoral não prolongado como um filamento, nadadeira caudal truncada com margens levemente arredondadas, dois poros supraorbitais s6 contra-laterais, olhos orientados dorsalmente, boca subterminal, abertura anal e urogenital no meio do espaço entre a margem da nadadeira pélvica e a origem da nadadeira anal, uma mancha escura na base dos barbilhões nasais, uma linha longitudinal mediana formada por manchas escuras enfileiradas do opérculo até próximo da nadadeira caudal, largura da cintura peitoral 13.1-17.7\% do comprimento padrão e altura do pedúnculo caudal 8.7-10.3 \% do comprimento padrão. Trichomycterus jacupiranga distingue-se das demais espécies de Trichomycterinae por apresentar o primeiro raio da nadadeira peitoral prolongado em um curto filamento, um poro supraorbital s6 fusionado, nadadeira pélvica cobrindo as aberturas anal e urogenital, aberturas anal e urogenital mais próximas da origem da nadadeira anal que da base da nadadeira pélvica, nadadeira caudal truncada com margens levemente arredondadas e pelas características morfométricas: comprimento da cabeça 20.7-22.4\% do comprimento padrão, comprimento pré-anal 57.1$70.9 \%$ do comprimento padrão, largura da cintura peitoral 17.4-20.6 \% do comprimento padrão, comprimento do tronco 33.6$37.5 \%$ do comprimento padrão, comprimento da nadadeira peitoral 16.8-22.7\% do comprimento padrão, comprimento da base da nadadeira dorsal 12.8-14.1 \% do comprimento padrão, comprimento da base da nadadeira anal 8.4-10.8 \% do comprimento padrão, largura da cabeça 90.6-104.6\% do comprimento da cabeça, comprimento do focinho 40.0-46.9\% do comprimento da cabeça, largura da boca 27.0-37.3 \% do comprimento da cabeça e diâmetro do olho 10.4-16.5 \% do comprimento da cabeça. Distribuição, características diagnósticas e dados ecológicos são apresentados para as duas espécies.

Key words: Freshwater fishes, Systematics, Neotropical, Trichomycterus tupinamba, Trichomycterus jacupiranga.

\footnotetext{
*Museu Paraense Emílio Goeldi, CZO, Laboratório de Peixes, Av. Magalhães Barata 376, CP 399, 66040-170 Belém, PA, Brazil. e-mail: wolmar@museu-goeldi.br

** Museu de Zoologia da Universidade de São paulo, CP 42494, 04218-970 São Paulo, SP, Brazil. e-mail: oyakawa@usp.br
} 


\section{Introduction}

The large systematic diversity of the catfish genus Trichomycterus with 96 nominal species and many others still undescribed has been the focus of studies of several authors (Fernandez \& Vari, 2000; Barbosa \& Costa, 2003; Fernandez \& Schaefer, 2003; de Pinna \& Wosiacki, 2003; Wosiacki, 2004; Wosiacki \& Garavello, 2004; and Bockmann \& Sazima, 2004). However, this large assemblage has been hypothesized as a non natural group (de Pinna, 1989, 1998), a situation that can only be solved with a comprehensive analysis of all species of Trichomycteridae, in a phylogenetic paradigm. Despite the question of the monophyly of Trichomycterus, the generic name continues to be used widely for this assemblage of species and will be used in this paper as well.

Species of the Trichomycterinae previously recorded for the rio Ribeira de Iguape Basin are: Trichomycterus davisi (Haseman), Trichomycterus sp. (Wosiacki \& Cury, 1990), T. iheringi (Eigenmann) (Bizerril, 1994), and Ituglanis proops (Miranda Ribeiro). One of us (OTO) recently conducted a comprehensive ichthyological inventory of this poorly-known basin which resulted in the discovery of one of the new species here described, from specimens collected in a tributary inside the conservation unit Parque Estadual de Jacupiranga, and the other new species from specimens collected in a distinct tributary close to this reserve.

The rio Ribeira de Iguape Basin (Southern Brazil, Fig. 1) lies within the Atlantic Rainforest, a heavily impacted habitat that has less than $5 \%$ of its original forest intact. The knowledge of the diversity of freshwater fishes of this environment is important to the preservation, conservancy and management of this endangered ecoregion.

\section{Materials and Methods}

All measurements were taken point-to-point, with dial calipers, on the left side of the specimen. Caudal peduncle length was taken from the origin of the last anal-fin ray to the

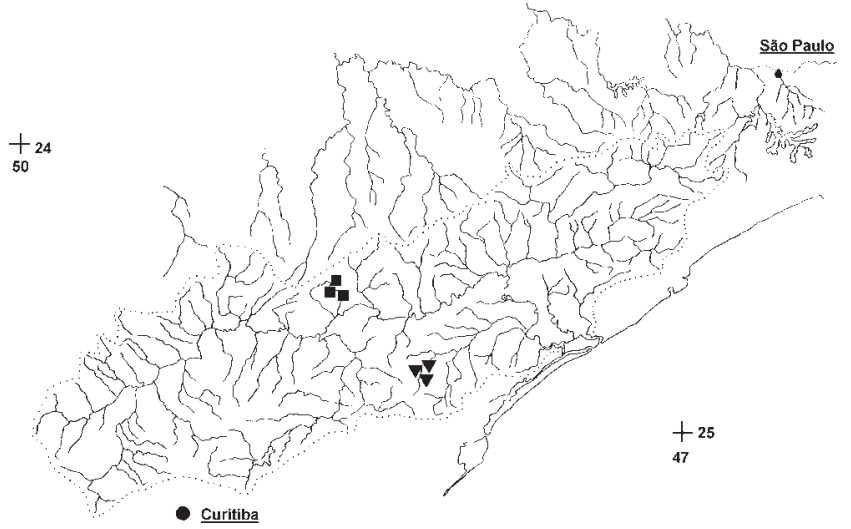

Fig. 1. Geographic distribution of Trichomycterus tupinamba (squares) and Trichomycterus jacupiranga (triangles). Dotted lines delimit Ribeira de Iguape river basin. middle of the caudal-fin base; caudal-peduncle depth was measured vertically through the midpoint of the caudal peduncle. Other measurements follow Tchernavin (1944). Dorsal and anal-fin ray counts include all branched and unbranched rays that were visible in transmitted light. Osteological preparations were made according to a modified version of the method of Dingerkus \& Uhler (1977). Trichomycterus jacupiranga not prepared for c\&s. The Weberian complex and compound caudal centrum are not included in vertebral counts. Sensory canal pores are numbered according to Arratia (1998). Drawings were prepared with the aid of a stereomicroscope and a camera lucida. Institutional abbreviations follow Leviton et al. (1985) with the addition of MHNCI for Museu de História Natural "Capão da Imbuia", Curitiba, Brazil, and NUP for Núcleo de Pesquisas em Limnologia, Ictiologia e Aqüicultura, Maringá, Brazil.

\section{Trichomycterus tupinamba, new species}

Figs. 2-4

Holotype. MZUSP 62382, 86.5 mm SL, Brazil, São Paulo: rio Betari, tributary of rio Ribeira de Iguape, in front of the camping area of Núcleo Santana, Parque Estadual Turístico do Alto Ribeira (PETAR), Iporanga, P. Gerhard, R. Moraes \& J. Sturve, 22 Jan 2000.

Paratypes. Brazil. São Paulo: MZUSP 84094, 4, 28.2-70.6 mm SL, collected with holotype; MZUSP 67911, 2 (C\&S), 44.4-54.0 mm SL, rio Betari, PETAR, Iporanga, P. Gerhard \& S. Buck, Mar 1999; MZUSP 63495, 1, 38.2 mm SL, rio Betari, Iporanga, S. Buck, 26 Jul 1996; MZUSP 62362, 1, 43.1 mm SL, rio Iporanga, Iporanga, R. Moraes \& J. Sturve, 20 Jan 2000; MPEG 7895, 5, 32.8-61.2 mm SL, rio Betari, PETAR, Iporanga, P. Gerhard, S. Buck, Sílvia, Jura, Anésio \& R. Moraes, Mar 1999.

Diagnosis. Trichomycterus tupinamba differs from all other species of the subfamily Trichomycterinae by the following unique combination of characters: first pectoral-fin ray not prolonged as a filament ( $v s$. prolonged), caudal fin truncate with attenuated edges ( $v s$. rounded), two paired supraorbital pores s6 ( $v s$. pores united as a single supraorbital pore s6), eye dorsally oriented (vs. dorsolaterally oriented), mouth subterminal ( $v s$. terminal), anal and urogenital openings mid-way between pelvic-fin margin and anal-fin origin ( $v s$. nearer to anal-fin origin), dark spot at base of nasal barbel (vs. dark spot absent), longitudinal row of dark spots along midline of flank from opercle to caudal-fin base ( $v s$. longitudinal lateral series of spots absent), pectoral girdle width 13.1-17.7\% SL, and caudal peduncle depth $8.7-10.3 \%$ SL.

Description. Morphometric data for holotype and paratypes are given in Table 1.

Body elongate, roughly cylindrical close to head and gradually more compressed towards caudal fin. Dorsal and ventral profiles of trunk slightly convex. Dorsal and ventral profiles of caudal peduncle straight (Figs. 2 and 3). Integument thick, especially over base of dorsal and anal fins. 


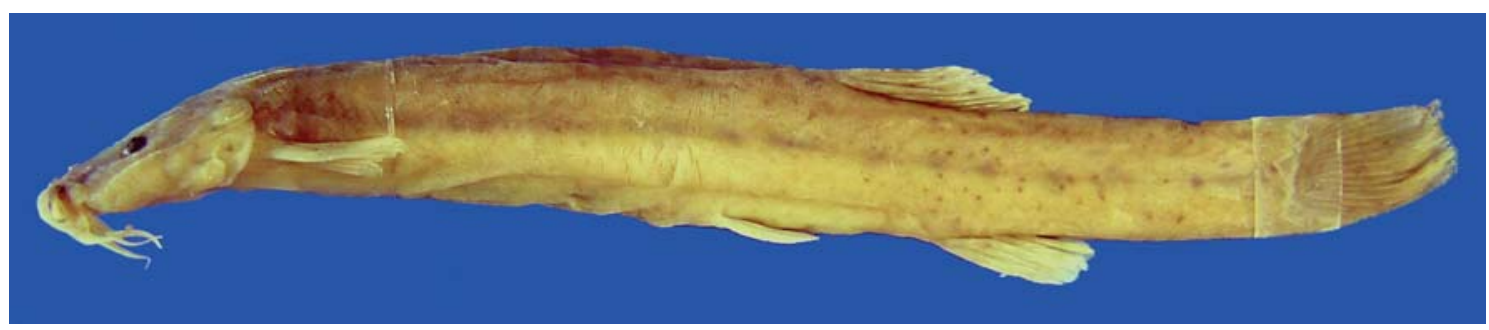

Fig. 2. Trichomycterus tupinamba, holotype, MZUSP 62382, $86.5 \mathrm{~mm}$, lateral view of the right side.

Head wide and depressed, trapezoidal in dorsal view, slightly longer than wide or as long as wide (75.8-100.9 \% $\mathrm{HL}$ ), width at posterior tip of opercle greater than width at nostril, anterior margin of snout slightly rounded (Fig. 4). Lateral region of eye slightly swollen by jaw muscles in large and small specimens. Dorsal and ventral profiles of head straight. Eye rounded, without well-defined rim, dorsally oriented, covered by thin skin in contact with center from surface of eyeball. Ocular structures readily visible on surface of skin, not deeply sunken. Orbital rim not free. Anterior nostril surrounded by fleshy flap of integument. Posterior nostril surrounded anteriorly by thin flap of integument. Anterior and posterior nostrils approximately same diameter as eye. Gill membranes thick, attached across isthmus only at anteriormost point, forming a small free fold across isthmus. Gill openings not constricted. Branchiostegal rays 7-8 (only 4 or 5 visible externally from below). Mouth subterminal, its corners laterally oriented. Lower lip with conspicuous lateral fleshy lobes, internal to origin of rictal barbel. Anterior margin of upper lip slightly rounded. Small papillae on external surface of upper lip and large papillae on inner surface of upper lip. Upper lip continuous with dorsal surface of head. Barbels long (nasal 35.5-54.2; maxillary 49.7-75.8; and rictal barbel length 41.7-60.6\% HL). Barbels with large base and narrowing gradually towards tip. Nasal barbel reaching to, or slightly beyond, posterior rim of eye; maxillary barbel reaching middle of interopercular patch of odontodes; rictal barbel reaching anterior most interopercular odontodes. Origin of nasal barbel on posterolateral portion of integument flap around anterior nostril. Interopercular patch of odontodes long, with 34-36 conical odontodes covered by thick integument (14-17 externally visible in alcohol specimens), external series smaller and straight, internal series larger, curved medially. Opercular patch of odontodes rounded, with 23-26 conical odontodes, anterior ones smaller and straight, posterior ones larger and curved medially. Sensory canals composed of complete supraorbital canal and incomplete infraorbital canal. Infraorbital anterior section pores il and i3, and posterior section pores i10 and i11. Supraorbital pores s1, s2 and s6. Two paired pores s6.

Pectoral-fin margin truncate, 8 rays, only first one unbranched, first the longest without a filamentous extension. Dorsal-fin margin semi circular, 12 rays $(9$ visible in intact specimens) rays, third through twelfth rays branched, third and fourth the longest. Anal fin slightly elongate in overall shape, smaller than dorsal fin, 9 rays (7 visible in intact speci- mens), third through ninth branched, third the longest, origin at vertical through seventh dorsal-fin ray. Pelvic-fin origin anterior to dorsal-fin origin, rounded margin, distant one half of its length from urogenital and anal openings, 5 rays, only first one unbranched, second and third rays longest. Caudalfin margin rounded with attenuated edges, distinctly deeper than remaining caudal region, 13 principal rays, dorsal and ventral external principal rays unbranched, branched rays splitting twice. Dorsal lobe procurrent rays 15-16. Ventral procurrent rays 10 . Only first dorsal and ventral caudal-fin accessory rays visible. Anal and urogenital openings midway between pelvic-fin margin and anal-fin origin.

Free vertebrae 39-40. Precaudal vertebrae 16-17. Caudal vertebrae 23. Ribs 14-15 pairs, first and second thickest, 13 and 14 longest, last rudimentary free ribs. Dorsal-fin pterygiophores 8 , first pterygiophore inserting anterior of neural spine of $19^{\text {th }}$ or $20^{\text {th }}$ free vertebrae. Anal pterygiophores 6 , first pterygiophore anterior of hemal spine of $23^{\text {rd }}$ to $25^{\text {th }}$ free vertebrae. Caudal skeleton pleurostyle, hypurals $4+5$, and hypural 3 , or hypurals $3+4+5$, and fused parahypural and hypurals $1+2$.

Color in alcohol. Refer to figures 2 to 4 for general view of color pattern in alcohol. Dorsal surfaces of head, trunk and caudal peduncle gray, darker over occipital region, becoming gradually lighter toward caudal peduncle. Dark stripe running between eye and anterior nostril. Thick skin surrounding opercular patch of odontodes dark. Narrow, dark midlateral stripe formed by closely spaced (sometimes continuous) black spots from opercle to vertical through anal-fin origin, and continuing posteriorly to caudal peduncle as series of irregularly spaced spots. Mid-lateral stripe darker in small specimens (28.2-58.8 $\mathrm{mm} \mathrm{SL}$ ), gradually lighter in larger specimens (59.6-86.5 mm SL). Surface under dark lateral stripe pale, without pigmentation in small specimens $(28.2-58.8 \mathrm{~mm}$ $\mathrm{SL}$ ), and with few scattered small spots near anal fin and ventral half of caudal peduncle. Dorsal surface of pectoral-fin base with few chromatophores, gradually scattered towards margin. Ventral surface of pectoral and pelvic fins unpigmented. Base of dorsal and anal fin with chromatophores, more scattered towards margin over rays. Dorsal fin darker than anal fin. Few chromatophores on caudal-fin rays, gradually more scattered towards margin. Base of nasal barbel dark, becoming gradually lighter towards the tip; maxillary barbel pale with few small dusky spots on dorsal surface. Rictal barbel unpigmented. Upper and lower lips unpigmented. 


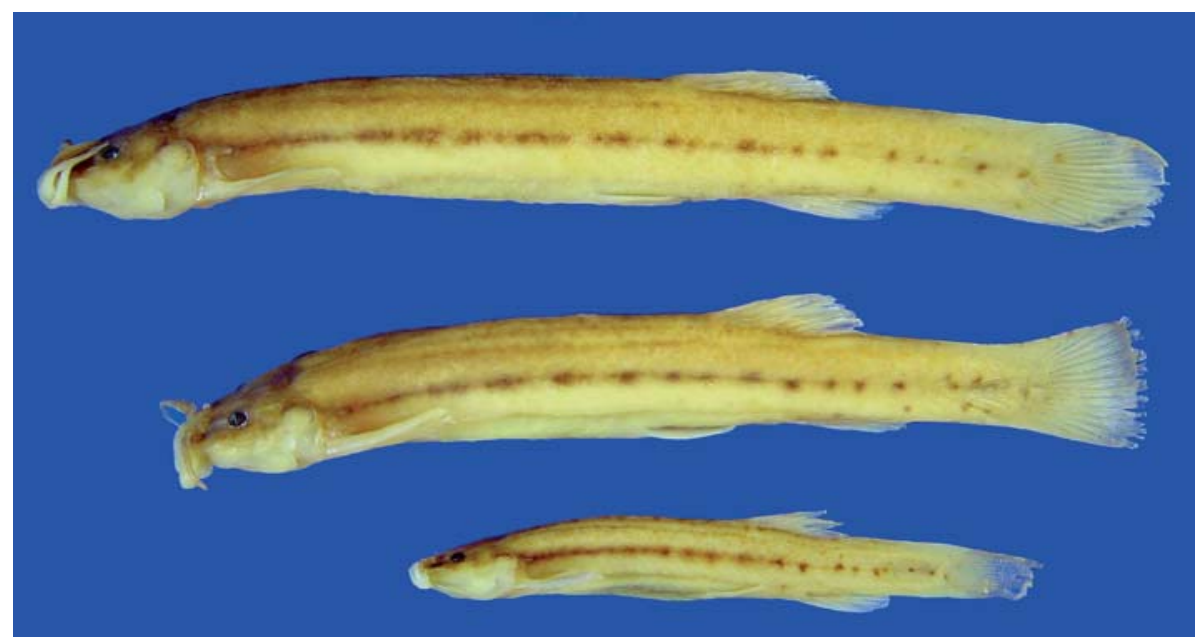

Fig. 3. Trichomycterus tupinamba, paratypes, MZUSP 84094, 28.2-70.6 mm SL.

Distribution. Known from the localities of the type series, rivers Betari and Iporanga, both tributaries of the rio Ribeira de Iguape.

Table 1. Morphometric and meristic data for Trichomycterus tupinamba and T.jacupiranga $(\mathrm{Hol}=$ Holotype $)$.

\begin{tabular}{|c|c|c|c|c|c|c|c|}
\hline & \multicolumn{3}{|c|}{$\begin{array}{c}\text { Trichomycterus } \\
\text { tupinamba }\end{array}$} & \multicolumn{4}{|c|}{$\begin{array}{c}\text { Trichomycterus } \\
\text { jacupiranga }\end{array}$} \\
\hline & $\begin{array}{c}\text { Hol } \\
(\mathrm{mm})\end{array}$ & Range & $\begin{array}{c}\text { Mean } \\
(n=12)\end{array}$ & $\begin{array}{c}\text { Hol } \\
(\mathrm{mm})\end{array}$ & \multicolumn{2}{|c|}{ Range } & $\begin{array}{c}\text { Mean } \\
(\mathrm{n}=6)\end{array}$ \\
\hline Standard length (SL) & 86.5 & 28.286 .5 & 55.6 & 57.4 & 33.5 & 57.4 & 49.2 \\
\hline \multicolumn{8}{|c|}{ Percents of Standard length } \\
\hline Head length (HL) & 15.1 & 17.520 .9 & 19.0 & 12.6 & 20.7 & 22.4 & 21.7 \\
\hline Predorsal length & 52.0 & 60.164 .0 & 62.4 & 35.3 & 59.6 & 62.7 & 61.7 \\
\hline Prepelvic length & 45.3 & 52.455 .5 & 54.2 & 31.8 & 51.8 & 57.8 & 54.9 \\
\hline Preanal length & 61.3 & 69.573 .5 & 71.1 & 40.7 & 57.1 & 70.9 & 68.9 \\
\hline Pectoral girdle width & 11.3 & 13.117 .7 & 14.8 & 11.0 & 17.4 & 20.6 & 19.1 \\
\hline Trunk length & 32.6 & 34.439 .6 & 37.7 & 21.2 & 33.6 & 37.5 & 34.9 \\
\hline Pectoral-fin length & 10.0 & $11.6 \quad 15.5$ & 13.6 & 10.1 & 16.8 & 22.7 & 17.7 \\
\hline Pelvic-fin length & 8.0 & $9.2 \quad 11.5$ & 10.5 & 6.3 & 10.6 & 11.6 & 11.1 \\
\hline $\begin{array}{l}\text { Distance pelvic-fin } \\
\text { base to anus }\end{array}$ & 10.8 & $11.7 \quad 15.1$ & 13.0 & 5.2 & 8.8 & 9.9 & 9.2 \\
\hline Caudal peduncle length & 19.5 & $18.7 \quad 22.5$ & 20.3 & 11.9 & 19.5 & 21.6 & 21.1 \\
\hline Caudal peduncle depth & 7.5 & $8.7 \quad 10.3$ & 9.7 & 7.1 & 9.0 & 12.4 & 11.0 \\
\hline Body depth & 10.3 & 11.614 .1 & 12.4 & 8.3 & 12.0 & 14.9 & 14.1 \\
\hline Dorsal-fin base length & 10.0 & 10.012 .8 & 12.0 & 7.7 & 12.8 & 14.1 & 13.8 \\
\hline Anal-fin base length & 6.7 & 6.59 .0 & 7.8 & 5.0 & 8.4 & 10.8 & 9.8 \\
\hline \multicolumn{8}{|c|}{ Percents of Head lenght } \\
\hline Head width & 15.2 & 75.8100 .9 & 85.3 & 12.0 & 90.6 & 104.6 & 95.6 \\
\hline Nasal barbel length & 5.5 & $34.5 \quad 54.2$ & 47.2 & 6.7 & 33.3 & 60.0 & 55.6 \\
\hline Maxillary barbel length & 7.5 & 49.775 .8 & 60.4 & 8.0 & 63.5 & 70.0 & 65.7 \\
\hline Rictal barbel length & 6.5 & 41.760 .6 & 46.6 & 5.8 & 40.0 & 55.0 & 46.4 \\
\hline Snout length & 7.0 & 37.347 .4 & 45.1 & 5.9 & 40.0 & 46.8 & 45.0 \\
\hline Interorbital width & 3.5 & 18.126 .3 & 22.8 & 2.7 & 18.7 & 24.0 & 22.5 \\
\hline Mouth width & 5.0 & $26.3 \quad 38.9$ & 31.9 & 4.7 & 27.0 & 37.3 & 32.1 \\
\hline Eye diameter & 1.4 & 9.313 .8 & 12.1 & 1.6 & 10.4 & 16.5 & 13.7 \\
\hline \multicolumn{8}{|c|}{ Counts } \\
\hline Dorsal rays & II,7 & II,7 & & II,7 & & I,7 & \\
\hline Pectoral rays & $\mathrm{I}, 7$ & $\mathrm{I}, 7$ & & $\mathrm{I}, 7$ & & $\mathrm{I}, 7$ & \\
\hline Pelvic rays & $\mathrm{I}, 4$ & $\mathrm{I}, 4$ & & $\mathrm{I}, 4$ & & I,4 & \\
\hline Anal rays & II,5 & II,5 & & II,5 & & $\mathrm{I}, 5$ & \\
\hline Caudal rays & $\mathrm{I}, 11, \mathrm{I}$ & $\mathrm{I}, 11, \mathrm{I}$ & & $\mathrm{I}, 12, \mathrm{I}$ & $\mathrm{I}, 11$ & $1, I-I, 12$ & \\
\hline Free vertebrae & & $39-40$ & & & & & \\
\hline Precaudal vertebrae & & $16-17$ & & & & & \\
\hline Caudal vertebrae & & 23 & & & & & \\
\hline Dorsal procurrent rays & & $15-16$ & & & & & \\
\hline Ventral procurrent rays & & 10 & & & & & \\
\hline
\end{tabular}

Etymology. The specific name tupinamba is the name of the indigenous tribe who lived in the eastern region of the São Paulo State in the XVI and early XVII centuries. Tupinamba, in Tupy language, meaning the first or the ancient, relationships to the indigenous people. A noun in apposition. It is especially interesting because according to Wosiacki (2002), Trichomycterus sp. n. (rio Betari) (=T. tupinamba) is the basalmost species in the assemblage Trichomycterus sensu strictu.

Ecological notes. The rio Betari at PETAR, the type locality of Trichomycterus tupinamba, is a clearwater river with strong to moderate current flowing over rocky beds intercalated with pools in karstic area. The river runs in an alluvial valley bordered by adjacent hills, and the riparian vegetation is composed of relatively well-preserved forest. Bellow the PETAR there are several human settlements near the rio Betari which release sewage into the river.

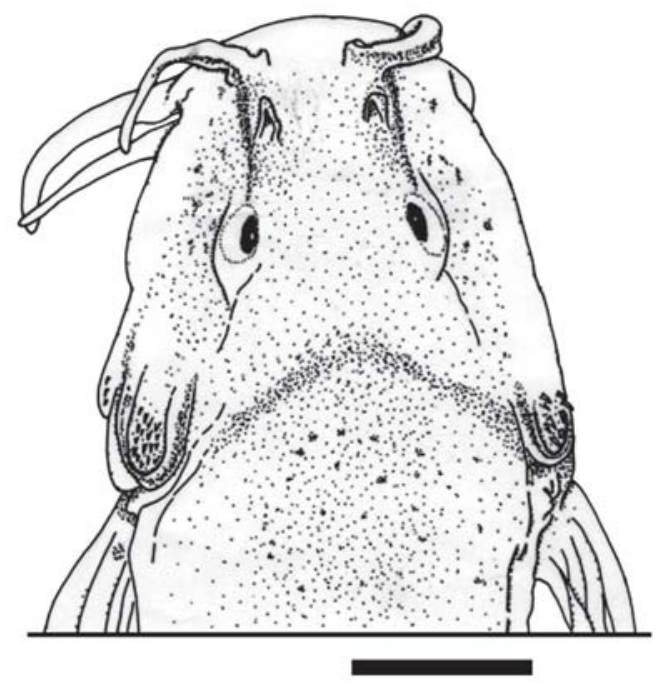

Fig. 4. Trichomycterus tupinamba, holotype, MZUSP 62382 , $86.5 \mathrm{~mm}$, dorsal view of the head. Scale bar $=5 \mathrm{~mm}$. 


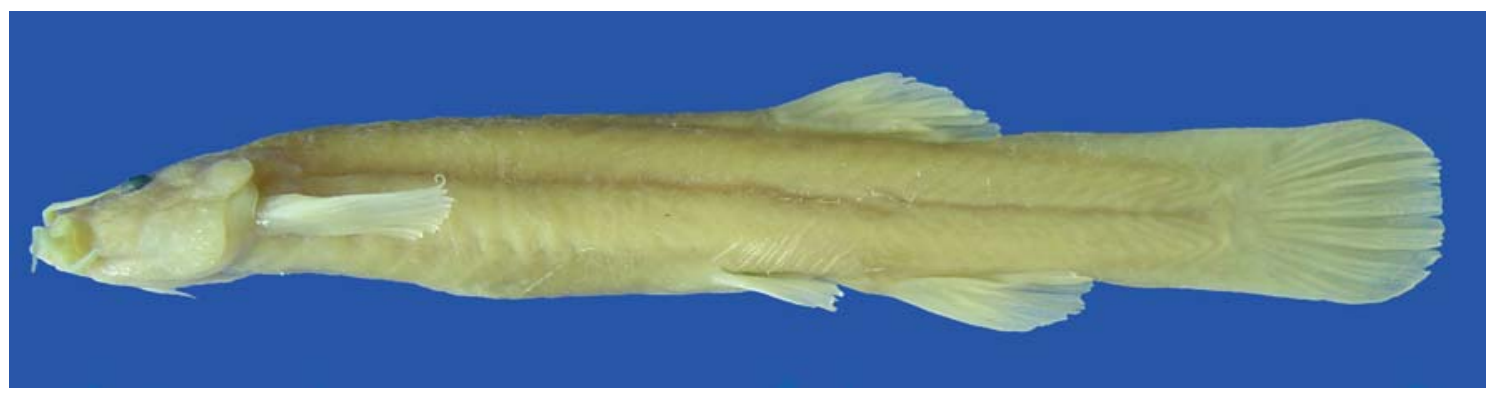

Fig. 5. Trichomycterus jacupiranga, holotype, MZUSP 67818, 57.4 mm.

Trichomycterus tupinamba and other siluriforms are found associated with stones and vegetable debris on the bottom. The following species of fish occur syntopically with Trichomycterus tupinamba: T. davisi, Isbrueckerichthys alipionis (Gosline), Neoplecostomus ribeirensis Langeani, Harttia kronei Miranda-Ribeiro, Rhamdioglanis frenatus Ihering, Chasmocranus lopezi Miranda-Ribeiro, Bryconamericus microcephalus (Miranda-Ribeiro), and Characidium pterostictum Gomes.

\section{Trichomycterus jacupiranga, new species}

Figs. 5-6

Holotype. Brazil, São Paulo: MZUSP 67818, 57.4 mm SL, rio do Queimado, Parque Estadual de Jacupiranga, Cajati, O. T. Oyakawa, A. Akama, J. C. Nolasco, A. C. Paixão \& R. T. Nasakumi, 9 Mar 2001.

Paratypes. MZUSP 84095, 1, 33.5 mm SL; MZUSP 67819, 1, 47.6 mm SL; MZUSP 67820, 1, 50.0 mm SL; MZUSP 67821, 1, $51.0 \mathrm{~mm}$ SL; MZUSP 67822, 1. $48.3 \mathrm{~mm}$ SL; all collected with holotype.

Diagnosis. Trichomycterus jacupiranga differs from all other species of the subfamily Trichomycterinae by the following unique combination of characters: first pectoral-fin ray prolonged as short filament ( $v s$. not prolonged), one supraorbital pore 56 fused ( $v s$. two supraorbital pores s6 paired), pectoralfin rays 8 ( $v s .7$ or 6 ), pelvic fin covering anal and urogenital opening ( $v s$. not covering), anal and urogenital opening closer to anal-fin origin than to pelvic-fin base ( $v s$. midway between anal-fin origin and pelvic-fin base), caudal fin truncated with attenuated edges ( $v s$. rounded or truncated without attenuated edges), and the following morphometric characteristics: head length 20.7-22.4\% SL, and head width 90.6-104.6\% HL.

Description. Morphometric data for holotype and paratypes are given in Table 1.

Body elongate, roughly cylindrical just posterior of head and gradually more compressed towards caudal fin. Profile of trunk straight dorsally and slightly convex ventrally. Dorsal and ventral profiles of caudal peduncle straight (Fig. 5). Integument thick, especially over base of dorsal and anal fins.

Head wide and depressed, trapezoidal in dorsal view, as long as wide (90.6-104.6\% HL), width at posterior tip of opercle greater than width at nostril, anterior margin of snout rounded (Fig. 6). Lateral region of eye slightly swollen by jaw muscles in large and small specimens. Dorsal profile of head straight in lateral view, ventral profile convex. Eye rounded, without well-defined rim, dorsally oriented, covered by thin skin in contact with center from surface of eyeball. Ocular structures readily visible on surface of skin, not deeply sunken. Orbital rim not free. Anterior nostril surrounded by fleshy flap of integument. Posterior nostril surrounded anteriorly by thin flap of integument. Anterior and posterior nostrils approximately same diameter as eye. Gill membranes thick, attached across isthmus only at anterior most point. Gill openings not constricted. Branchiostegal rays 3 or 4 externally visible from below. Mouth subterminal, its corners laterally oriented. Lower lip with conspicuous lateral fleshy lobes internal to origin of rictal barbel. Anterior margin of upper lip rounded. Small papillae on external surface of upper lip and large papillae on inner surface of upper lip. Upper lip continuous with dorsal surface of head. Barbels long (nasal 33.3-60.0; maxillary 63.570.0; and rictal barbel length 40.0-55.0\% HL). Barbels with large base and narrowing gradually towards tip. Nasal barbel reaching to midway between posterior rim of eye and base of anterior opercular odontodes; maxillary barbel reaching tip of posterior opercular odontodes; rictal barbel reaching base of posteriormost interopercular odontodes. Origin of nasal barbel on posterolateral portion of integument flap around anterior nostril. Interopercular patch of odontodes long, 33-38 conical odontodes covered by thick integument, external series smaller and straight and internal series larger, curved medially. Opercular patch of odontodes rounded, with 20-23 conical odontodes, anterior ones smaller and straight, posterior ones larger and curved medially. Sensory canals composed of complete supraorbital canal and incomplete infraorbital canal. Infraorbital anterior section pores il and i3, and posterior section pores $\mathrm{i} 10$ and i11. Supraorbital pores s1, s2 and a single s6 pore at interorbital space.

Pectoral-fin margin truncate, 8 rays, only first one unbranched; first ray longest with a short filamentous extension. Dorsal-fin margin semicircular when expanded, 9 rays, third through ninth branched, fourth longest. Anal fin slightly elongate in overall shape, slightly smaller than dorsal fin, 7 rays, third through seventh branched, fourth longest, origin at vertical through last dorsal-fin ray. Pelvic-fin origin anterior to dorsal-fin origin, rounded margin, covering urogenital 
and anal openings, 5 rays, only first one unbranched, second and third longest. Caudal fin truncated with attenuated edges, distinctly deeper than remaining caudal region, 13 principal rays, dorsal and ventral external principal rays unbranched, branched rays splitting three times. Only first dorsal and ventral caudal-fin accessory rays visible. Anal and urogenital openings closer to anal-fin origin than to pelvic-fin base.

Color in alcohol. Refer to figures 5 and 6 for general view of color pattern in alcohol. Color pattern similar in all examined (33.5-57.4 mm SL) specimens. Dorsal surface of trunk uniform gray, gradually lighter laterally. Body with narrow, poorly defined mid-lateral stripe from head to caudal peduncle. Dorsal surface of head gray, darker over neurocranium. Skin covering jaw musculature lighter than surrounding area and with few chromatophores. Nasal barbel with few chromatophores on dorsal surface. Maxillary and rictal barbels unpigmented. Ventral surfaces of head, trunk and caudal peduncle unpigmented. Pectoral fin with few chromatophores restricted to dorsal surface of base of first ray. Pelvic and anal fins unpigmented. Dorsal fin with few chromatophores over base of rays. Caudal fin hyaline.

Distribution. Known only from the type locality.

Etymology. The species name, jacupiranga, refers to the type locality, Parque Estadual de Jacupiranga, município de Cajati, São Paulo, Brazil. Jacupiranga is also the indigenous Tupylanguage name for a species of bird native to the region (Penelope obscura - Cracidae), commonly known as the dusky-legged guan, and comes from yaku (a bird) and piranga (red). Treated here as a noun in apposition.

Ecological notes. Rio do Queimado, in the stretches where $T$. jacupiranga was collected, is a medium-sized, clearwater river with strong to moderate current flowing mainly over sand beds, intercalated with some rocky portions. Even though the type locality is inside the Conservation Unit Parque Estadual de Jacupiranga, the riparian vegetation is highly degraded and in certain areas there are many banana plantations. The microhabitat occupied by Trichomycterus jacupiranga is in sand beds within which they bury themselves; a behavior also seen in T. alternatus (Eigenmann) (pers. obs.). The following species of fishes occur syntopically with Trichomycterus jacupiranga: Astyanax sp., Characidium pterostictum Gomes, Hisonotus gibbosus (Miranda-Ribeiro), Hypostomus tapijara Oyakawa, Akama \& Zanata, Kronichthys lacerta (Nichols), Parotocinclus maculicauda (Steindachner), Pseudotothyris obtusa (Miranda-Ribeiro), Schizolecis guntheri (Miranda-Ribeiro), and T. zonatus.

Remarks. The two new species, Trichomycterus tupinamba and $T$. jacupiranga, were included in the genus Trichomycterus for reasons similar to those discussed in Fernandez \& Vari (2000), Bockmann et al. (2004), Wosiacki (2004), and Wosiacki (2005). Both species are recorded from

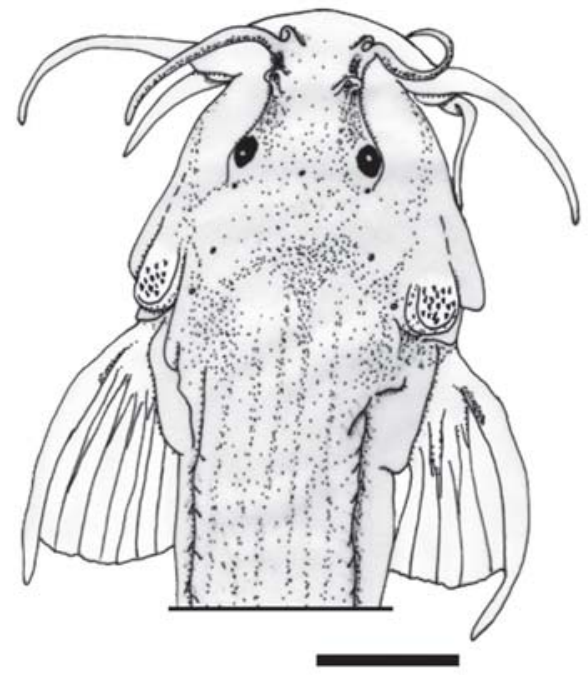

Fig. 6. Trichomycterus jacupiranga, holotype, MZUSP 67818, $57.4 \mathrm{~mm}$, dorsal view of the head. Scale bar $=5 \mathrm{~mm}$.

rio Ribeira de Iguape basin, south and southeastern Brazil, where six species of trichomycterids were previously recognized: Trichomycterus davisi from the headwaters (Wosiacki \& Cury, 1992), Microcambeva ribeirae Costa, Lima \& Bizerril, Listrura camposi (Miranda-Ribeiro), Ituglanis proops, Trichomycterus iheringi, and T. brasiliensis (Lütken) based in Eigenmann (1918; as T. brasiliensis tristis Lütken).

No autapomorphies were observed for T. tupinamba or $T$. jacupiranga, and their diagnoses are possible by combinations of characters. The absence of large or small spots or stripes on dorsum of head and trunk distinguishes each species from a large assemblage of species which possess these characteristics and are distributed in south and southeastern Brazil, including: T. albinotatus Costa, T. alternatus (Eigenmann), T. auroguttatus Costa, T. bahianus Costa, T. brasiliensis, T. candidus (Miranda-Ribeiro), T. castroi de Pinna, T. caudofasciatus Alencar \& Costa, T. davisi, T. diabolus Bockmann et al., T. giganteus Lima \& Costa, $T$. goeldii Boulenger, T. itacambirussu Triques \& Vono, T. itatiayae Miranda-Ribeiro, T. jequitinhonhae Triques \& Vono, T. landinga Triques \& Vono, T. longibarbatus Costa, $T$. mboycy Wosiacki \& Garavello, T. maracaya Bockma \& Sazima, T. mimonha Costa, T. mirissumba Costa, T. naipi Wosiacki \& Garavello, T. pantherinus Alencar \& Costa, T. potschi Barbosa \& Costa, T. taroba Wosiacki \& Garavello, T. reinhardti (Eigenmann), T. stawiarski (Miranda-Ribeiro), T. variegatus Costa, T. vermiculatus (Eigenmann), and T. zonatus. Trichomycterus tupinamba and T. jacupiranga are distinguished from T. papilliferus Wosiacki \& Garavello which has extremely short maxillary (18-31\% HL) and rictal barbels (12$30 \% \mathrm{HL}$ ), and conspicuous papillae in the ventral surface of head, all of which were proposed as autapomorphies by Wosiacki \& Garavello (2004). 
Trichomycterus tupinamba is distinguished from $T$. plumbeus and T. guaraquessaba by having a color pattern composed of a narrow dark mid-lateral stripe from opercle to vertical through anal-fin origin, absent in the later species. Trichomycterus tupinamba and T. paolence are similar to each other in having a dark mid-lateral stripe from the opercle to a vertical line through the anal-fin origin. However, T. paolence has a dark stripe "along the side of the back and a stripe along the edge of the belly" (Eigenmann, 1918), the latter of which is absent in T. tupinamba. Trichomycterus tupinamba has eight pectoral-fin rays, the first is the longest, without a filamentous extension, which helps differentiate it from $T$. triguttatus (Eigenmann) and the holotype of T. paolence both of which have with six pectoral-fin rays and the first ray prolonged as a filament.

Trichomycterus jacupiranga has one s6 supraorbital pore fused, distinct from $T$. concolor and T. immaculatus, which have two paired s6 supraorbital pores. Trichomycterus jacupiranga shares with $T$. nigricans one s6 supraorbital pore and the first pectoral-fin ray prolonged as a short filament (Arratia, 1998), and is distinguished from this species by having eight pectoral-fin rays $v s$. nine rays (Arratia, 1998) in $T$. nigricans. Trichomycterus jacupiranga shares with $T$. triguttatus the first pectoral-fin ray prolonged as a long filament and is distinguished from that species by the presences of only one supraorbital s6 pore $v s$. two paired supraorbital s6 pores.

\section{Comparative material. See Wosiacki (2004).}

\section{Acknowledgements}

The authors are grateful to A. Prudente (MPEG) for suggestions that have improved the manuscript. We are indebted to P. Buckup (MNRJ), R. Reis (MCT), C. Pavanelli (NUP), and V. Abilhôa (MHNCI) for loan of material. We thank to W. Eschmeyer (CAS) and B. Chernoff (FMNH) for their advice and help during the visit of W. Wosiacki to the USA to examine type material. We thank to A. Aleixo by the help to identify the scientific name of the bird "jacupiranga". The present paper was partially supported by FAPESP (Fundação de Amparo à Pesquisa do Estado de São Paulo), and by financial support for international students provided by the Lakeside Foundation (CAS). The collection field trip was supported by (CNPq - Conselho Nacional de Desenvolvimento Científico e Tecnológico / FINEP - Financiadora de Estudos e Projetos / CAPES - Coordenação de Aperfeiçoamento de Pessoal de Nível Superior; project No. 661058/1997-2, entitled "Conhecimento, Conservação e Utilização Racional da Diversidade da Fauna de Peixes do Brasil" sponsored by Naércio A. Menezes (MZUSP), and State of São Paulo Research Foundation (FAPESP) within the BIOTA/FAPESP The Biodiversity Virtual Institute Program (www.biotasp. org.br); Project No. 00/04300-9, entitled "Diversidade de peixes de riachos e cabeceiras da Bacia do Rio Ribeira de Iguape no Estado de São Paulo" sponsored by Osvaldo Oyakawa.

\section{Literature Cited}

Arratia. G. 1998. Silvinichthys, a new genus of trichomycterid catfishes from the Argentinian Andes, with redescription of Trichomycterus nigricans. Ichthyological Exploration of Freshwaters, 9(4): 347-370.

Barbosa, M. A. \& W. J. E. M. Costa. 2003. Trichomycterus potschi (Siluriformes, Loricarioidei): a new trichomycterid catfish from coastal stream of southeastern Brazil. Ichthyological Exploration of Freshwaters, 14(3): 281-287.

Bizerril, C. R. S. F. 1994. Descrição de uma nova espécie de Trichomycterus (Siluroidei, Trichomycteridae) do Estado de Santa Catarina, com uma sinopse da composição da família Trichomycteridae no leste Brasileiro. Arquivos de Biologia e Tecnologia, 37(3): 617-628.

Bockmann, F. A. \& I. Sazima. 2004. Trichomycterus maracaya, a new catfish from the upper rio Paraná, southeastern Brazil (Siluriformes: Trichomycteridae), with notes on the T. brasiliensis species-complex. Neotropical Ichthyology, 2: 61-74.

Bockmann, F. A., L. Casatti \& M. C. C. de Pinna. 2004. A new species of trichomycterid catfish from the Rio Paranapanema basin, southeastern Brazil (Teleostei: Siluriformes), with comments on the phylogeny of the family. Ichthyological Exploration of Freshwaters, 15: 225-242.

Dingerkus, G. \& L. D. Uhler. 1977. Enzyme clearing of alcian blue stained whole small vertebrates for demonstration of cartilage. Stain Technology, 52: 229-232.

Eigenmann, C. H. 1918. The Pygidiidae, a family of South American catfishes. Memoirs of the Carnegie Museum, 5(7): 259-398.

Fernandez, L. A. \& S. A. Schaefer. 2003. Trichomycterus yuska, a new species from high elevation of Argentina (Siluriformes: Trichomycteridae). Ichthyological Exploration of Freshwaters, 14(4): 353-360.

Fernandez, L. A. \& R. P. Vari. 2000. New species of Trichomycterus (Teleostei: Trichomycteridae) lacking a pelvic fin and girdle from the Andes of Argentina. Copeia, 2000: 990-996.

Leviton, A. E., R. H. Gibbs Jr., E. Heal \& C. E. Dawson. 1985. Standards in herpetology and ichthyology. Part I. Standard symbolic codes for institutional resource collections in herpetology and ichthyology. Copeia, 1985: 802-832.

de Pinna, M. C. C. 1989. A New Sarcoglanidine catfish, phylogeny of its subfamily, and an appraisal of the phyletic status of the Trichomycterinae (Teleostei, Trichomycteridae). American Museum Novitates, 2950: 1-39.

de Pinna, M. C. C. 1998. Phylogenetic relationships of neotropical Siluriformes: historical overview and synthesis of hypotheses. Pp. 279-330 In: L. R. Malabarba, R.E. Reis, R. P. Vari, Z. M. S. Lucena \& C. A. S. Lucena (eds.). Phylogeny and classification of Neotropical fishes, Edupucrs, Porto Alegre. 603p.

de Pinna, M. C. C. \& W. B. Wosiacki. 2003. Family Trichomycteridae. Pp. 270-290. In: R. E. Reis, S. O. Kullander, C. J. Ferraris (eds.). Check list of the freshwater fishes of South and Central America. Edipucrs, Porto Alegre. 729p. 
Tchernavin, V. 1944. A revision of some Trichomyctrinae based on material preserved in the British Museum (Natural History). Proceedings of the Zoological Society of London, 114: 234-275.

Wosiacki, W. B. 2002. Estudo das relações Filogenéticas de Trichomycterinae (Teleostei, Siluriformes, Trichomycteridae) com uma proposta de classificação. Unpublished PhD. Dissertation, Universidade de São Paulo, São Paulo. $324 \mathrm{p}$.

Wosiacki, W. B. 2004. New species of the catfish genus Trichomycterus (Siluriformes, Trichomycteridae) from the headwaters of the rio São Francisco basin, Brazil. Zootaxa, 592: 1-12.

Wosiacki, W. B. 2005. A new species of Trichomycterus (Siluriformes: Trichomycteridae) from south Brazil and redescription of T. iheringi (Eigenmann). Zootaxa, 1040: 49-64.
Wosiacki, W. B. \& M. R. Cury. 1990. Inventário preliminar da ictiofauna da Área Especial de Interesse Turístico do Marumbi (Paraná) com comentários ictiogeográficos. Arquivos de Biologia e Tecnologia, 33(2): 379-392.

Wosiacki, W. B. \& J. C. Garavello. 2004. Five new species of Trichomycterus (Siluriformes: Trichomycteridae) from the rio Iguaçu (rio Paraná Basin), southern Brazil. Ichthyological Exploration of Freshwaters, 15(1): 1-16.

Received December 2004

Accepted November 2005 